\title{
The Twilight of Print Media in the New Media Era (The Strategy of Kedaulatan Rakyat in Maintaining its Reader's Loyalty)
}

\author{
C. A. Subekti ${ }^{1}$, B. Setiawan ${ }^{2}$ \\ Department of Communication Science, Faculty of Social Sciences \\ Universitas Negeri Yogyakarta, Indonesia. \\ ${ }^{1}$ chikaamazella21@gmail.com, ${ }^{2}$ bennisetiawan@uny.ac.id
}

\begin{abstract}
This research aims at analyzing the strategy of Kedaulatan Rakyat newspaper in maintaining its existence amid the growing of new media. This research employs a qualitative approach. The informant of the research is the editor in chief of the Kedaulatan Rakyat newspaper. Data analysis was carried out utilizing the Miles \& Huberman model. The results of this research indicate that Kedaulatan Rakyat keeps its reader's loyalty by taking some efforts. First, Kedaulatan Rakyat stands independently and hold the principle of voicing conscience based on the Pancasila press firmly. Second, Kedaulatan Rakyat adapts to regional traditions, by prioritizing local news. Beside publishing local news, a typically local (Javanese) rubric is promoted, namely Mbah Kalam. Mbah Kalam rubric presents the dating calculation system in the Javanese calendar. This typical strength enhances Kedaulatan Rakyat in sustaining the loyalty of its readers (consumers).
\end{abstract}

Keywords. Reader's loyalty, convergence, Kedaulatan Rakyat

\section{Introduction}

The digital era poses a threat to print media. The print media needs to transform, otherwise, it will disappear. The print media company needs to strive to increase its sales in order to survive. But, the sale priority should not neglect the quality of its news and appearance. The quality of news becomes one of the important things in the midst of the abundant news published in online portals.

This reality becomes a challenge for print media publishers. However, the print media has its own characteristics such as complete, clear, and detailed. Online media offers timely and speedy news publication. Nevertheless, online news can only be accessed utilizing sophisticated tools. In fact, not all people have such tools. The success of online media is highly impacted by technological sophistication [1]

When the print media industry is hard to survive due to the increase of paper prices, they must transform themselves to master digital technology which is developing, has developed, and will develop. The world figures such as Roger F. Fidler, Bill Gates, Rupert Murdoch, and Philip Meyer classify four implications of the widespread use of paperless newspaper technology.

First, the print media technology has shifted to the paperless newspaper business that is cheaper in both its production and distribution costs. Second, the people's lifestyles in accessing mass media have changed, from opening sheets to using mobile screens. Third, media content will be more varied due to the unlimited reach. Fourth, mass media companies increasingly expand their network so that multimedia convergence occurs. Fifth, print media companies will 
close down automatically [2].

The changes in the consumption of the selected media indicate the changes in people's lifestyles. The development of technology cannot be avoided. So, newspapers that promote digital technology must be able to live side by side if they do not want to be replaced. The emergence of print, digital, and newspaper versions of the newspaper has directly impacted the changing consumption patterns in the newspaper. This is because the newspaper is an information medium that directly deals with technological changes and the demographics of its readers [3]

The sustainability of print media in the midst of online media development is still debatable. The main indication that becomes the focus of the debate is the challenges faced by the media industry. The challenge deals with how to grasp mass audiences which have been fragmented in a narrower segment. In this situation, there is a shift in the pattern of public consumption of the media. The rules in media consumption may change, but the level of media consumption will always be high [4]

To cope with the growing of new media, conventional media must maintain the credibility of the information they present. Credibility can be built through journalist professionalism that uphold the ethics of journalism. Thus, the news presented should be factual and verified. This must be reinforced so that print media can still survive [2]

Research [5] on Kompas newspaper's strategy in the transformation of media convergence shows that the media industry, especially print, must undergo a transformation otherwise they won't survive. One of the transformations that should be realized is changing the strategy. In this case, print media must consider its publication medium. They are encouraged not only by utilizing paper-based but also the electronic medium for a news publication. Therefore, print media may integrate newspaper content into electronic content as its strength.

As a print newspaper publishing company, Kedaulatan Rakyat is required to perform changes. Kedaulatan Rakyat as the oldest newspaper in Indonesia, which was established on September 27, 1946, needs to transform in order to maintain its existence. This research was conducted as an effort to investigate the extent of the Kedaulatan Rakyat daily newspaper strategy in solving problems pertaining to the reader's migration.

\section{Method}

This research utilizes a qualitative approach. The qualitative approach serves to understand and explore a central phenomenon [6]. This approach is employed to thoroughly examine the experiences of Kedaulatan Rakyat in maintaining its reader loyalty. The data collected in this research were analyzed to describe the Kedaulatan Rakyat newspaper strategy in sustaining the loyalty of its readers.

\section{Results And Discussions}

The existence of the media is closely related to the audience. So, the media keep the loyalty of its readers amid the increasingly tight media competition [7]. The strategy used by the Kedaulatan Rakyat to sustain its reader loyalty refers to Gordon's theory [8].

Gordon [8] classifies five models of convergence in media organizations. The first model is the ownership convergence. Kedaulatan Rakyat is a local newspaper that was founded in 1945 
and has been operating especially in the Special Province of Yogyakarta and Central Java. As a long-sustaining print media, Kedaulatan Rakyat does not want to be left behind by fostering its publication in online media.

The founder of Kedaultan Rakyat, the oldest newspaper in Indonesia, is HM. Samawi and M. Wonohito where his son, Soemadi Martono Wonohito, was appointed as their successor. Kedaultan Rakyat and two other print media, namely Merapi and Minggu Pagi Newspaper, are managed under PT. BP. Kedaulatan Rakyat Group.

The convergence of ownership deals with the company's rule which regulates news content or promotion division for various platforms such as print, online, and television managed under the same company [8]

Kedaulatan Rakyat carries out development by uniting its corporate management. Kedaulatan Rakyat and Minggu Pagi newspaper are led by Octo Lampito as an Editor in Chief, whereas Merapi Newspaper which has different reader segments is led by Swasto Dayanto. Nevertheless, marketing management remains under PT BP Kedaulatan Rakyat [9]. In addition, Kedaulatan Rakyat expands its business through its newly developed media platforms such as krjogja.com since June 1, 2009, YouTube KR TV, and 107.2 FM radio.

The second convergence is tactics convergence. The convergence of information exchanges performed by the Kedaulatan Rakyat occurs since 2009 when krjogja.com was established. The establishment of krjogja.com was aimed at reaching broad reader segments, by allowing the access for worldwide readers. The newly developed media benefit to cope with print media limitations such as space and time limitation [10].

In order to promote the ease of information exchange, Kedaulatan Rakyat developed a unified newsroom system in early May of 2020. Formerly, the media management which was incorporated under the Kedaulatan Rakyat Group was fragmented but management was unified since early May of 2020. The Kedulatan Rakyat, krjogja.com, and Minggu Pagi are managed by the same editor in chief, while the Merapi newspaper is led by different editor in chief due to its typical reader segments. However, the marketing of the entire Kedaulatan Rakyat media Group remains the same [11].

In addition to exchanging information, cross-promotions on print and online platforms are also performed. Kedaulatan Rakyat promotes krjogja.com regularly and vice versa. Advertising services can be carried out on both platforms.

The convergence of tactics that utilizes the newsroom system has changed the editorial structure of the Kedaulatan Rakyat where newsroom editorial staffs are added. With this new system, print and online editors can gather news that will be published on each platform. The collection of issues for news writing is performed at the discussion at the planning meetings. The results of the meetings are submitted to the newsroom editors. The role of newsroom editors is to assign reporters or journalists. Decision making must be carried out based on the approval of the newsroom editors. In the changing structure, the company also adds graphics for infographics.

This change conforms to the concept of the third media convergence, namely structural convergence. This structure convergence focuses on how the work division and organizational restructuring is realized to meet the needs of convergence.

The next convergence is coverage convergence. The management of the Kedaulatan Rakyat believes that if internal cooperation is carried out optimally, it will gain maximum results. So, the journalists of Kedaulatan Rakyat are required to have multitasking skills for dealing with all platforms both print and online.

Today, journalists are not only required to acquire 6M competencies (searching, possessing, obtaining, storing, processing, and delivering information) but also they must develop various 
aspects which include knowledge, expertise, skills, and attitudes when carrying out their duties [12]. Journalists are assigned to do a reportage utilizing a rolling system. According to the editor in chief of the Kedaulatan Rakyat, Octo Lampito, the reporters must be able to do various things (multitasking) [11]. This ability is developed by applying the rolling system for reportage assignments. In addition, to ensure the quality publication, the Kedaulatan Rakyat sets an S1 degree as a minimum standard for journalist educational background. This minimum requirement of educational background may encourage a journalist to become an expert in reporting.To support the convergence of coverage, journalists are trained. The development of journalists' capacity is carried out by providing opportunities for the journalists to join various training such as the Press Council training three times a year, PWI center training twice a year, Bank Indonesia twice a year, and the Financial Services Authority twice a year. The company does not conduct a specific training, but the evaluation and discussion at the meeting are carried out to sharpen the critical thinking of the journalists.

The last convergence is the convergence of presentation. In this case, the presence of new media allow the journalists to no longer present news in a single platform but on various platforms. Therefore, training for the journalists continue to be carried out in order to improve the publication quality. The content presented in the online media platform tends to be more concise and promotes the speedy exchange of information, while in print media, the news is presented in deeper elaboration. Therefore, it takes longer for print media in presenting the information.

To enhance the need for convergence, Kedaulatan Rakyat also has photographers, but they are not always involved in every reportage. They are assigned to perform photo editing for the newspaper and sometimes they are tasked to take a photo in important reportage of the newspaper as well as make videos to be uploaded to YouTube and social media platforms.

With regard to the supporting facilities, Kedaulatan Rakyat has not fully provided the supporting facilities as the company does not facilitate the supporting tools in implementing the convergence system. Employees use the supprting tools they have.

In addition to Gordon's five theories above, Kedaulatan Rakyat also has a specific strategy to keep its reader loyalty. The first strategy is remaining to be independent and being consistent with its principle. When many press companies have continually expanded their business since 1990, Kedaulatan Rakyat remains independent. Along with the times development, the management of PT. BP. Kedaulatan Rakyat keeps evaluating its performance. Responding to the rapid changes of communication and press technology, Kedaulatan Rakyat applies the principles of modern management.The principle of modern management, according to the editor in chief of Kedaulatan Rakyat, deals with how to maintain and retain readers both print and online suited to the development of technology. In order to sustain the reader's trust, Kedaulatan Rakyat must adapt independently to the time changes.

Modern management relies on the base of thought, such as concepts, analysis, human resources, and social responsibility in organizations. This management system is developed on best practices with new approaches, techniques, directions, and attitudes [13].

The newspaper keeps holding the philosophy of the Pancasila Press as a basis for running the company. The Pancasila press system was originated from the belief of Madikin Wonohito. According to Wonohito, the press system must be in line with the philosophy of the state. The philosophy of other countries cannot be applied in Indonesia, and vice versa.

Human life, in its nature, can not be separated from the physical and spiritual aspects. The established material/physical aspects must be aligned with established spiritual aspects (believe in God). In this case, the Indonesian national press must be based on the philosophy of the state, namely Pancasila. Indeed, Kedaulatan Rakyat does not yet apply Pancasila Press perfectly but 
various efforts will be carried out continously.From the establishment until the present time, Kedaulatan Rakyat has a firm standing in voicing the conscience of the people. In carrying out this vision, this newspaper upholds the ideal role of the press as social control. Criticizing is carried out in a proper manner.

Law Number 40 of 1999 Article 3 states that the function of the national press is a medium of information, education, entertainment, and social control. In addition, the national press also functions as an economic institution [14].Kedaulatan Rakyat becomes the watchdog of the country's situation that criticizes anything that goes wrong by promoting a journalistic code of ethics such as prohibiting to make fake news or hoax.The criticism is solely aimed at making the criticized party aware of their misconduct so that they can be better. That is called an ideal criticism which is in accordance with the nature of reform.

Beside criticizing, Kedaulatan Rakyat also receives criticism from the public through letters and "Pikiran Pembaca" rubric. This continues to be realized as an evaluation for improvement.

The element in mass communication includes the SMCR model namely Source, Message, Channel, and Receive which are added with other elements namely encoding, decoding, feedback, and interference (noise) [15]. Thus, the Kedaulatan Rakyat provides a rubric that accommodates the aspirations of the community to see the feedback given by the community.

The second strategy is adjusting to the tradition. In a relatively long period of time, Kedaulatan Rakyat is able to adapt to the tradition. In order to sustain, Kedaulatan Rakyat must be able to maintain its existence by understanding the dynamics and desires of the people. Newspapers are supposed to be present to deal with the changes of times.

Vandijk [16] explains that mass communication in general serves many functions, one of them is the ability to adapt to the environment. Consumer self-adjustment to their environment is enhanced with mass media. In this case, mass media helps someone know more about their environment by providing information.

The adaptation to traditions that are constantly sustained by the Kedaulatan Rakyat is indicated by its news choice on local/regional issues. This news choice can bring the Kedaulatan Rakyat closer to local readers in the Yogyakarta and Central Java regions.

Another rubric in Kedaulatan Rakyat that contains local content is the dating calculation system in Javanese calendar which is known as "Mbah Kalam". The emergence of this rubric stems from the aspiration of the public posted to the editorial department. In the beginning, the dating calculation system was carried out by Mbah Tom (earlier Javanese traditional elder) from 1967 to 1980. It was continued by the editorial secretary of the Kedaulatan Rakyat, Suproyo and now it is performed by Mbah Kalam.

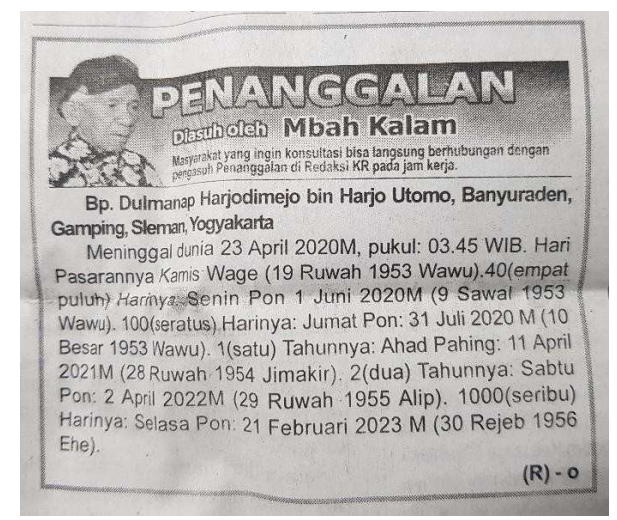

Fig.1. The Dating Calculation System in Javanese Calender performed by Mbah Kalam 
In this modern time, traditional dating experts are still sought. Through days and dates calculation, someone's fortune and destiny can be predicted. The dating presented by Mbah Kalam rubric in Kedaulatan Rakyat includes determining a good day or date for marriage, for living in a new house, and for commemorating 7 to 1000 days of one's death.

The existence of Mbah Kalam rubric in Kedaulatan Rakyat newspaper has successfully attracted the audience from various levels of society to ask questions about the dating. This is because the dating calculation is carried out using a particular knowledge and certain formulas carefully. This old dating calculation system is inherited by the ancestors. Until now, dating consultations are served at the editorial office during office hours.

As a newspaper in general, Kedaulatan Rakyat must be able to serve its reader's needs both young and old. For young readers segments, Kedaulatan Rakyat has provided a rubric of "Kaca dan Kawanku". While special rubrics that are adjusted to the Javanese Culture such as Mbah Kalam, Mekar Sari, and Kandha Raharja are addressed to the old readers. In line with classical theory [17], the function of mass media as social inheritance includes the inheritance of norms and culture from one generation to the next.

The third strategy is maintaining the product quality. The company's management strategy in maintaining its reader's loyalty is to keep to the product quality. Quality not only attach to the newspapers, but also covers other aspects such as print quality, good service, and so on.

Aw [18] states that print media are all print products that are used as a means of delivering a message. Kedaulatan Rakyat as a print media that serves as a means of delivering messages is always trying to improve its print products by updating the technology in press printing.

In the early 1970s, Kedaulatan Rakyat follows the flow of technological developments. Samawi and Wonohito intentionally bought offset printing machines from Australia under the brand name Goss Community. Since the start of the new era of printing, the press industry has been able to grow from a high printing press that is only capable of printing 1000 copies per hour, to 14000 copies with a Goss offset machine. Even, nowadays there is a Uniman printing press which can print more than 45 thousand copies per hour.

The efforts for improving the publication have been carried out by Kedaulatan Rakyat. Beside publishing Kedaulatan Rakyat and the Merapi newspaper, PT Badan Penerbit Mataram Press also publishes weekly newspaper named Minggu Pagi. With regard to commercial printing, Kedaulatan Rakyat also has a special printing company namely PT Grafika Wangsa Bhakti.

To maintain the product quality, Kedaulatan Rakyat always conducts editorial plan meetings on each edition at least twice a week. Also, evaluation meetings are conducted in each issue of publication. In rubric selection, several aspects are evaluated.

To reinforce the discipline of the internal editorial team, rewards and penalties are applied. Initially, the reward was vouchers such as hotel and shopping vouchers. But, the employees now receive honorarium as rewards.

The employee who violates the ethics will be warned verbally. When it doesn't work, they will get a warning letter. So far, no one receives the warning letter, they are aware of their fault and do better things. This is realized to carry out supervisory management functions.According to [19], the functions of media management include planning, organizing, and mobilizing and supervising to ensure that the process runs as it is.

The fourth strategy is getting close to the community. In maintaining trust, Kedaulatan Rakyat newspaper also cooperates to organize events such as the Daihatsu festival, university anniversary, and etc. Dufly [20] mentions that consumer loyalty is indicated by the cooperation with the community. In this regard, Kedaulatan Rakyat establishes cooperation with various parties. 
Kedaulatan Rakyat also foster people's conscience. Various humanitarian activities are carried out which include the 2004 Aceh Tsunami, the 2006 Yogyakarta-Central Java Earthquake, the 2010 Merapi Eruption, the 2015 Banjar Negara Landslide, and the current situation of the corona outbreak.

The consumer loyalty to the Kedaulatan Rakyat newspaper can be viewed from the humanitarian activities initiated by Kedaulatan Rakyat by inviting people to give charity during the Covid-19 pandemic. People flocked to participate in this activity by donating money and entrust Kedaulatan Rakyat to distribute and manage the donations.

From April 08 to May 29, 2020 Kedaulatan Rakyat collected donations from the public which reached 261 million rupiah. This is certainly in line with Nurwidayat [21] that one of the consumer loyalty indicators can be assessed from trust, namely a consumer's trust in a product.

\section{Conclusions}

Kedaulatan Rakyat maintains the reader's loyalty by taking some efforts. Firstly, Kedaulatan Rakyat stands independently and hold the principle of voicing conscience based on the Pancasila press firmly. The Pancasila press is interpreted as a guide for humans to live within the physical and spiritual frame. Material establishment must necessarily be followed by spiritual establishment. That is what Pancasila taught, which was applied in the journalism practices of Kedaulatan Rakyat. Secondly, Kedaulatan Rakyat adapts to regional traditions by promoting local news. In addition to local news, a typically local (Javanese) rubric was created, namely Mbah Kalam. Mbah Kalam rubric contains the traditional dating calculation system in Javanese calendar. This typical strength enhances Kedaulatan Rakyat in sustaining the loyalty of its readers (consumers).

\section{References}

[1] S. Steensen, "Online journalism and the promises of new technology: A critical review and look ahead". Journalism studies, vol. 12, no. 3, pp. 311-327. 2011.

[2] S. Kusuma, "Posisi media cetak di tengah perkembangan media online di Indonesia". Jurnal InterAct, vol. 5, no. 1, pp. 56-71. 2016.

[3] H. Taneja, J. G. Webster, E. C. Malthouse, \& T. B. Ksiazek, "Media consumption across platforms: Identifying user-defined repertoires". New media \& society, vol. 14, no. 6, pp. 951-968. 2012

[4] N. Couldry, S. Livingstone, \& T. Markham, Media consumption and public engagement: Beyond the presumption of attention. London: Palgrave Macmillan. 2016.

[5] A. Sugiya, "Strategi transformasi konvergensi media, study kasus grand strategi harian Kompas" Doctoral dissertation, Tesis. Program Pasca Sarjana Ilmu Komunikasi Manajeman

Komunikasi Universitas Indonesia. 2012.

[6] J. W. Creswell, \& J. D. Creswell, Research design: Qualitative, quantitative, and mixed methods approaches. London: Sage publications. 2017.

[7] I. G. D. Yudha, Studi komparatif tingkat kepuasan pembaca Radar Lampung dan Tribun Lampung. Bandar Lampung: Universitas Lampung. 2014.

[8] R. Gordon, "The meanings and implications of convergence". In K. Kawamoto (Ed), Digital journalism: Emerging media and the changing horizons of journalism. USA: Rowman and Littlefield Publishers, Inc. 2003.

[9] Wawancara dengan Octo Lampito, Pemimpin Redaksi Kedaulatan Rakyat, Kamis, 5 Maret 2020, 
pukul 13.30-14.30 WIB

[10] V. Nawiroh, Komunikasi Massa. Bogor: Ghalia Indonesia. 2016.

[11] Wawancara dengan Octo Lampito, Pemimpin Redaksi Kedaulatan Rakyat, Selasa, 28 April 2020, pukul 12.00-13.00 WIB.

[12] D. M. Hamna, "Konvergensi media terhadap kinerja jurnalis (studi kasus: Fajar TV dan Fajar FM). Jurnal Dakwah Tabligh, vol. 19, no. 1, pp. 58-83. 2018.

[13] E. B. Dent \& P. Bozeman, "Discovering the foundational philosophies, practices, and influences of modern management theory", Journal of Management History, vol. 20, no. $\quad 2, \quad$ pp. 145-163. 2014.

[14] A. Suharyanto, "Surat kabar sebagai salah satu media penyampaian informasi politik pada partisipasi politik masyarakat". Jurnal Administrasi Publik (Public Administration Journal), vol. 6, no. 2, pp. 123-136. 2016.

[15] D. McQuail, Mass communication theory: An introduction. London: Sage Publications, Inc. 1987.

[16] T. A. van Dijk, Discourse and communication: New approaches to the analysis of mass media discourse and communication (Vol. 10). Berlin-New York: Walter de Gruyter. 2011.

[17] H. D. Laswell, The structure and function of communication in society. New York: The communication of ideas. 1948.

[18] S. Aw, Komunikasi sosial budaya. Yogyakarta: Graha Ilmu. 2010.

[19] M. I. Fazryansyah, H. Agustina, \& N. Nuruzzaman, "Manajemen redaksional pada surat kabar harian umum Radar Cirebon (studi deskriptif kualitatif manajemen redaksional pada surat kabar harian umum Radar Cirebon periode Januari-Mei 2013)”. Jurnal Aspikom, vol. 2, no. 2, pp. 85-102. 2014.

[20] D. L. Duffly, "Internal and external factors which affect customer loyalty". Journal of Consumer Marketing, vol. 20, no. 5, pp. 480-485. 2003.

[21] A. Nurwidayat, "Analisis pengaruh pelayanan dan keragaman barang terhadap loyalitas konsumen (studi pada Pasar Bunder di Sragen). Doctoral dissertation, Universitas Muhammadiyah Surakarta. 2015. 